\title{
Eksplorasi dan Identifikasi Tanaman Aren (Arenga pinnata Merr) di Kabupaten Tapanuli Selatan
}

\section{Exploration and Identification of Aren Plant (Arenga pinnata Merr) in Tapanuli Selatan Regency}

Parmanoan Harahap ${ }^{1 *}$, Rosmayati ${ }^{2}$, Erwin Masrul Harahap ${ }^{2}$, Darmadi Erwin Harahap ${ }^{3}$, Fitra Syawal Harahap*4

${ }^{1}$ Program Studi Agroteknologi, Fakultas Pertanian Universitas Graha Nusantara Padang Sidimpuan, 22718

${ }^{2}$ Program Studi Agroteknologi, Fakultas Pertanian Universitas Sumatera Utara Medan, 20155

${ }^{3}$ Program Studi Agroteknologi, Fakultas Pertanian Universitas Graha Nusantara Padang Sidimpuan, 22718

${ }^{4}$ Program Studi Budidaya Perkebunan, Fakultas Pertanian Universitas Tjut Nyak Dhien Medan 20123

*Corresponding author : parma_bona@yahoo.com

\section{ABSTRACT}

Aren (Arenga pinnata Merr) plants are plant have high economic value to be developed so that data is needed for developmentThe purpose of this research is to know the diversity of accession of sugar arenga in South Tapanuli Regency and classify the selection population to get high production. Eighty accessions arenga natural populations of four sub districts have been identified according to IPGRI and analyzed. The results show the formation of 4 clusters concluded that cluster 1 is a collection of accession arenga with phenotypic character suitable to produce fruit from female flowers. While cluster 3 is a group accession arenga with phenotypes character appropriate to produce nira (raw material of arenga sugar) from male flowers.

Keywords : Arenga plant, identification, phenotype character and production

\begin{abstract}
ABSTRAK
Penelitian ini bertujuan untuk mengetahui keanekaragaman aksesi aren yang tersebar di Kabupaten Tapanuli Selatan dan mengelompokkan populasi seleksi untuk mendapatkan produksi yang tinggi. Delapan puluh aksesi aren populasi alam asal empat kecamatan telah di identifikasi menurut IPGRI (International Plant Genetic Resources Institute, 1995) dan dianalisis. Hasil menunjukkan terbentuknya 4 cluster yang disimpulkan bahwa cluster 1 merupakan kelompok aksesi aren dengan karakter fenotip yang sesuai untuk memproduksi buah dari mayang bunga betina. Sedangkan cluster 3 merupakan kelompok aksesi aren dengan karakter fenotip yang sesuai untuk memproduksi nira (bahan baku gula aren) dari mayang bunga jantan.
\end{abstract}

Kata kunci : Tanaman aren, identifikasi, karakter fenotip dan produksi.

\section{PENDAHULUAN}

Kabupaten Tapanuli Selatan merupakan salah satu kabupaten yang ada di Propinsi Sumatera Utara. Ibu kota kabupaten ini adalah Sipirok dan kabupaten ini terbagi atas 14 (empat belas) kecamatan dengan luas wilayah $4.498,81 \mathrm{~km}^{2}$. Dimana luas lahan hutan 249.452 ha dan lahan pertanian 53.231 ha (BPS Tapsel, 2013). Dari seluruh luas daerah pertanian masih didominasi tanaman tahunan seperti karet, sawit, kakao, kopi dan salak. Sedangkan 
tanaman aren (Arenga pinnata Merr) masih tumbuh liar dan hampir menyebar diseluruh tanah masyarakat di Kabupaten Tapanuli Selatan (BPS Tapsel, 2013).

Tanaman aren ini merupakan sebuah potensi sumber daya lokal yang patut di kembangkan, hal ini terbukti bahwa tanaman aren yang tumbuh liar tersebut dimanfaatkan oleh petani sebagai tambahan pendapatan diluar pendapatan pokok sesuai dengan komoditi utama yang di usahakan. Tanaman ini unik kerena memiliki nilai ekonomis yang menjajikan, mulai dari akar sampai dengan pelepahnya dan secara tidak langsung memberi peranan penting yang turun-temurun terhadap masyarakat lokal yang mengusahakannya. Pertumbuhan aren masih berdasarkan kasih sayang alam kepada petani aren, karena belum ada perlakuan dari petani terhadap aren tersebut. Dan belum ada langkah pengembangan yang terprogram untuk membina masyarakat petani aren dan sekaligus melestarikan plasma nutfah tanaman aren (Pulungan, 2013).

Permasalahan mendasar yang dihadapi dalam pengembangan produksi nira dan gula aren di Kabupaten Tapanuli Selatan adalah : 1). Tanaman aren yang diusahakan (disadap) masih tumbuh liar sehingga belum ada teknik budidaya yang diterapkan, 2). Kurangnya pengetahuan tentang budidaya tanaman aren, sehingga tanaman ini tumbuh dan berproduksi secara liar, 3). Keterbatasan pengetahuan mengenai jenis dan keanekaragaman kultivar tanaman aren serta sifat-sifat unggulnya, 4). Tingginya keanekaragaman jenis dan luasnya penyebaran populasi mengakibatkan sulitnya mengetahui karakter yang berpengaruh terhadap produksi nira dan gula aren, 5). Rendahnya produksi nira dari tanaman aren menyebabkan terbatasnya produksi gula aren.
Luasnya penyebaran populasi serta diiringi dengan tingginya keanekaragaman tanaman aren ini mengakibatkan sulit untuk menduga tinggi atau rendahnya produksi nira. Sampai saat ini belum ada data dan informasi yang menjelaskan bagaimana karakter fenotip tanaman aren yang berproduksi, khususnya produksi nira sebagai bahan baku produk gula aren di Kabupaten Tapanuli Selatan.

Penelitian ini bertujuan untuk mengetahui dan mendapatkan keanekaragaman aksesi tanaman aren yang tersebar di Kabupaten Tapanuli Selatan.

\section{BAHAN DAN METODE}

Penelitian ini dilakukan dengan metode survei yang merupakan penelitian eksplorasi dengan cara menjelajah dan mengumpulkan berbagai aksesi tanaman aren yang ada di sentrasentra produksi gula aren di dua desa di empat kecamatan pada Kabupaten Tapanuli Selatan.

Tahapan dalam penelitian ini dilaksanakan dengan tiga tahap. Tahap pertama adalah eksplorasi dengan metode survei yang pengambilan sampel dilakukan secara purposive sampling yaitu teknik pengambilan sampel untuk dijadikan sampel berdasarkan kriteria yang ada setelah mengetahui karakteristik populasinya di sentrasentra produksi gula aren yang bertujuan untuk mengetahui daerah-daerah sasaran penelitian yang memiliki populasi tanaman aren.

Tahap kedua adalah identifikasi dan karakterisasi dilakukan berdasarkan karakter fenotip tanaman menurut IPGRI (International Plant Genetic Resources Institute, 1995) dengan mengamati objek individu tanaman.IPGRI belum mengeluarkan descriptor list tanaman aren karena tanaman aren belum familiar 
untuk dibudidayakan, namun ini bukan merupakan masalah atau hambatan untuk dapat mengidentifikasi karakter fenotiptanaman aren karena IPGRI telah mengeluarkan descriptor list tanaman kelapa yang merupakan satu famili dengan tanaman aren, maka descriptor list tanaman kelapa tersebut yang dijadikan sebagai panduandan acuan serta dimodifikasi sesuai dengan kebutuhan untuk dapat mengidentifikasi dan mengkarakterisasi tanaman aren.

Tahap ketiga adalah analisis data.

Data yang didapatkan dari lapangan digambarkan secara deskriptif. Selanjutnya,dilakukan analisis data dengan analisa statistik untuk melihat dengan menggunakan analisis faktor dan analisis cluster.

\section{HASIL DAN PEMBAHASAN}

Didapatkan 53 karakter fenotip yang diamati sesuai dengan descriptor list dari IPGRI. Dilakukan analisis factor untuk mengetahui karakter yang menimbulkan keragaman secara fenotip sehingga didapatkan 32 variabel karakter fenotip yang direduksi menjadi 6 faktor yang terbentuk. Hasil analisis pada Gambar 1. menunjukkan adanya kemiripan dan keragaman pada karakter fenotip berdasarkan jarak Euclid, sehingga terbentuk 4 kelompok (cluster) utama dari no inithin sroups) kesesı

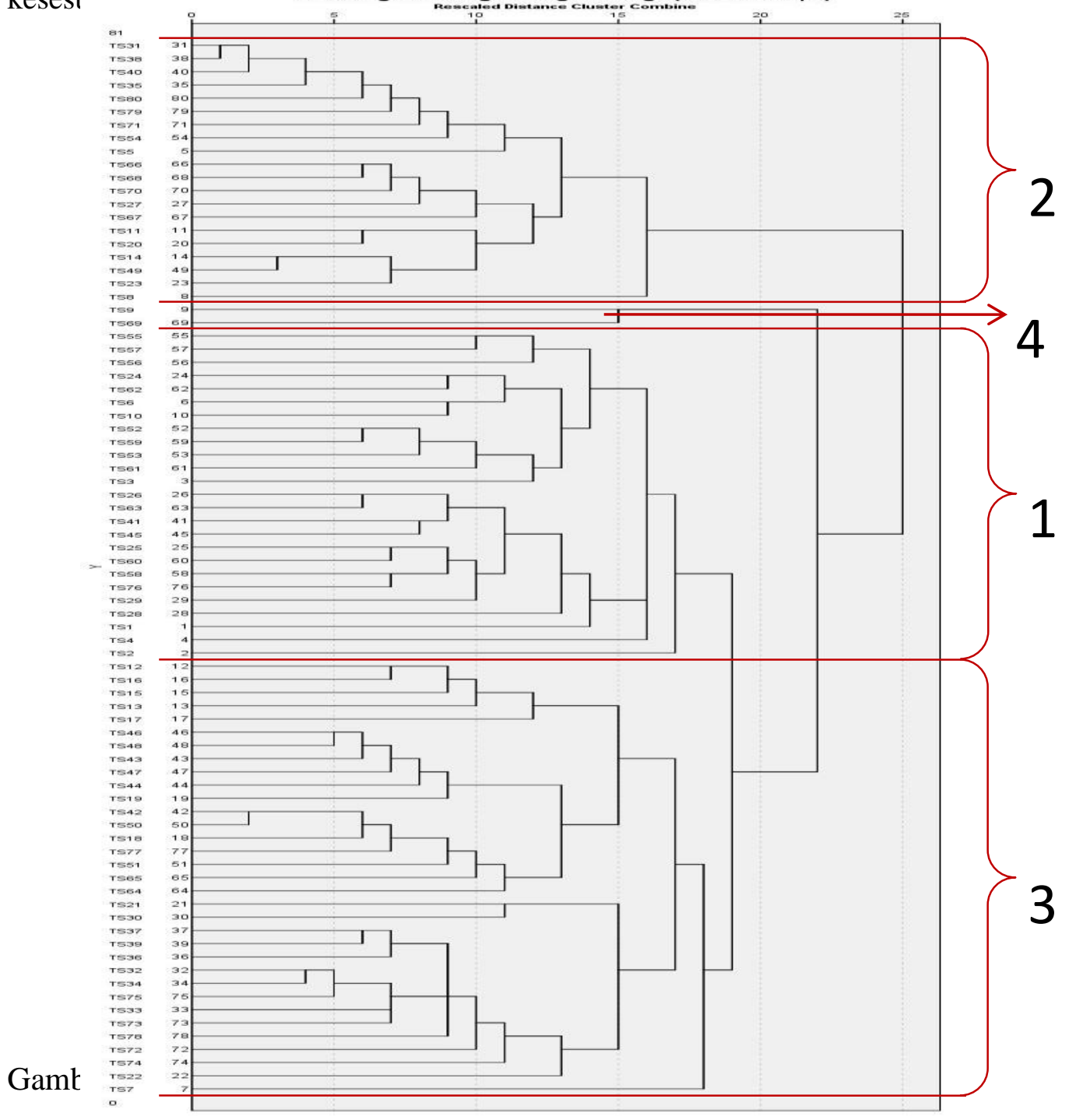


Cluster 1, merupakan kolompok aksesi aren dengan karakter fenotip yang sesuai untuk memproduksi buah dari mayang bunga betina. Adapun aksesi tersebut adalah 6 aksesi di Desa Sinyior (Kec. Angkola Selatan), 5 aksesi di Desa Sitaratoit (Kec. Angkola Barat), 2 aksesi di Desa Pasar Sempurna dan 8 aksesi di Desa Aek Sabaon (Kec. Marancar), 3 aksesi di Desa Baringin serta 1 aksesi di Desa Parau Sorat (Kec. Sipirok).

Cluster 2, merupakan kolompok aksesi aren dengan karakter fenotip yang tidak memiliki mayang bunga betina. Adapun aksesi tersebut adalah 2 aksesi di Desa Sinyior dan 3 aksesi di Desa Situmbaga (Kec. Angkola Selatan), 2 aksesi di Desa Sitaratoit dan 4 aksesi di Desa Pagaran (Kec. Angkola Barat), 1 aksesi di Desa Pasar Sempurna dan 1 aksesi di Desa Aek Sabaon (Kec. Marancar), 4 aksesi di Desa Baringin serta 3 aksesi di Desa Parau Sorat (Kec. Sipirok).

Cluster 3, merupakan kolompok aksesi aren dengan karakter fenotip yang sesuai untuk memproduksi nira (bahan baku gula aren) dari mayang bunga jantan. Adapun aksesi tersebut adalah 1 aksesi di Desa Sinyior dan 7 aksesi di Desa Situmbaga (Kec. Angkola Selatan), 3 aksesi di Desa Sitaratoit dan 6 aksesi di Desa Pagaran (Kec. Angkola Barat), 7 aksesi di Desa Pasar Sempurna dan 1 aksesi di Desa Aek Sabaon (Kec. Marancar), 2 aksesi di Desa Baringin serta 6 aksesi di Desa Parau Sorat (Kec. Sipirok).

Cluster 4, Merupakan kolompok aksesi aren dengan karakter fenotip yang tidak memiliki mayang bunga jantan. Adapun aksesi tersebut adalah 1 aksesi di Desa Sinyior (Kec. Angkola Selatan) dan 1 aksesi di Desa Baringin (Kec. Sipirok).

\section{SIMPULAN}

Hasil eksplorasi dan identifikasi 80 aksesi aren pada 4 kecamatan di
Kabupaten Tapanuli Selatan memiliki keragaman yang bervariasi dan terdapat 4 kelompok utama dengan tingkat kemiripan sebesar $75 \%$ atau keragaman sebesar $25 \%$.

\section{DAFTAR PUSTAKA}

Amilda, Y, 2014. Eksplorasi Tanaman Pisang Barangan (Musa acuminata) Di Kabupaten Aceh Timur. Program Studi Agroekoteknologi. Pasca Sarjana Fakultas Pertanian. Universitas Sumatera Utara.

Badan Pusan Statistik Kabupaten Tapanuli Selatan, 2016. Kabupaten Tapanuli Selatan Dalam Angka (Tapanuli Selatan Regency in Figures), 2016.

http://tapanuliselatankab.bps.g o.id/

Harahap, 2013. Kajian Produktivitas Tanaman Aren berdasarkan Status Hara Tanah dan Morfologi Tanaman pada Skuen Tinggi Tempat di Kabupaten Tapanuli Selatan. Universitas Sumatera Utara. Medan.

Khairiyah, 2013. Analisis Keragaman Genetik Tanaman Aren (Arenga pinnata Merr) di Tapanuli Selatan dengan Menggunakan Marka RAPD (Random Amplified Polymorphic DNA). Program magister agroekoteknologi fakultas pertanian. Universitas Sumatera Utara. Medan.

IPGRI, 1995.Descriptors for Coconut (Cocosnucifera L). International Plant Genetic Resources Institute. Roma. Italy.

http://indoplasma.or.id/deskript or.htm. 
Pulungan, 2013. Analisis Pengembangan Agroindustri Gula Aren dan Gula Semut di Kabupaten
Tapanuli Selatan. Universitas Andalas.Padang 